\title{
Analysis And Comments On The Consultative Document: International Framework For Liquidity Risk Measurement, Standards And Monitoring
}

\author{
Jacques Préfontaine, Université de Sherbrooke, Sherbrooke Qc, Canada \\ Jean Desrochers, Université de Sherbrooke, Sherbrooke Qc, Canada \\ Lise Godbout, Université de Sherbrooke, Sherbrooke Qc, Canada
}

\begin{abstract}
The market turmoil that began in mid-2007 re-emphasized the importance of liquidity to the functioning of financial markets and the banking sector. In December 2009, the Basel Committee on Banking Supervision (BCBS) of the Bank for International Settlements (BIS) released a consultative document entitled: "International Framework for Liquidity Risk Measurement, Standards and Monitoring". Interested parties were invited to provide written comments by April $16^{\text {th }} 2010$. Given our interest in promoting sound liquidity risk management and supervision, three members of the Chair responded to the BIS request. Today, we share with you a summary of our analysis and comments. Our work first supports the adoption of the BCBS proposals on two new liquidity risk management standards which take the form of a 30-day minimum liquidity coverage ratio (LCR) combined with a one-year minimum net stable funding ratio (NSFR), both to be accompanied by a mandatory set of market-related monitoring tools. Second, we share with you several general comments and suggestions we formulated on the following topics: the need for better coordination, both domestically and internationally between macro and micro-prudential supervision, the need to formulate more precise liquidity risk requirements on foreign currency funding, the importance and usefulness of public financial disclosure, suggestions on extending the use of market-related monitoring rules and metrics. Third, we also share with you more specific comments and suggestions formulated on the following topics : areas of further work like intra-group and cross border liquidity risk management, selling to gauge market liquidity, clarifying LCR and NSFR definitions, credit rating downgrades, and defining required stable funding categories. Fourth, the results of the analysis support the need to promote a more level business and supervisory playing field for all internationally active banks. Last but not least, we draw the risk-return and financial implications for Canadian banks of the adoption of the BCBS proposals for liquidity risk management and supervision.
\end{abstract}

Keywords: BCBS, BIS, FRB, liquidity risk, risk management, supervision.

\section{INTRODUCTION}

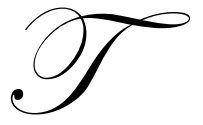

he market turmoil that began in mid-2007 re-emphasized the importance of liquidity to the functioning of financial markets and the banking sector. In December 2009, the Basel Committee on Banking Supervision (BCBS) of the Bank for International Settlements (BIS) released a consultative document entitled: "International Framework for Liquidity Risk Measurement, Standards and Monitoring". Interested parties were invited to provide written comments by April 16th 2010. Given our interest in promoting sound liquidity risk management and supervision, three members of the Chair responded to the BIS request. Today, we share with you a summary of our analysis and comments. Our work first supports the adoption of the BCBS 
proposals on two new liquidity risk management standards which take the form of a 30-day minimum liquidity coverage ratio (LCR) combined with a one-year minimum net stable funding ratio (NSFR), both to be accompanied by a mandatory set of market-related monitoring tools. Second, we share with you several general comments and suggestions we formulated on the following topics: the need for better coordination, both domestically and internationally between macro and micro-prudential supervision, the need to formulate more precise liquidity risk requirements on foreign currency funding, the importance and usefulness of public financial disclosure, suggestions on extending the use of market-related monitoring rules and metrics. Third, we also share with you more specific comments and suggestions formulated on the following topics : areas of further work like intra-group and cross border liquidity risk management, selling to gauge market liquidity, clarifying LCR and NSFR definitions, credit rating downgrades, and defining required stable funding categories. Fourth, the results of the analysis support the need to promote a more level business and supervisory playing field for all internationally active banks in the area of required central banks reserves and domestic deposit insurance programs.

\section{GENERAL COMMENTS}

The comments which follow are aimed at making a positive contribution to the consultative process instigated last December by the Basel Committee on Banking Supervision (BCBS) of the Bank for International Settlements (BIS) in order to better define and improve the "International framework for liquidity risk measurement, standards and monitoring (2009)".

The first general comment deals with the macroprudential orientation of financial regulation and more specifically in the liquidity risk management framework. In paragraph 4 of the BCBS document, the Committee explains its objective of improving internationally active banks' resiliency to financial disturbances by adopting an international framework for liquidity risk management and supervision. We agree that the adoption of the two proposed regulatory standards and the accompanying monitoring tools represents an important step in improving individual banks' resiliency to liquidity stresses. But it has been suggested that improving the resiliency of the financial system as a whole is equally important. One way of increasing financial system resiliency is to place more emphasis on the macroprudential or systemic orientation of the regulatory framework as recently set forth by G20 leaders $(2009 \mathrm{a}, 2009 \mathrm{~b}, 2009 \mathrm{c})$. A macroprudential approach naturally implies promoting and monitoring the resiliency of financial institutions on an individual basis, but also taking into consideration the systemic risks associated with the collective activities of each financial institution. As a result, adopting the proposed supervisory and liquidity risk management framework alone will not be sufficient. Increased attention has also to be devoted to monitoring the financial system as a whole and to put in place the necessary mechanisms to this end.

The second general comment deals with the concentration of funding problems that could arise as a result of the foreign currency funding activities of internationally active banks. Banks' potential concentration of funding problems by significant counterparties, instrument/product and by significant currencies are discussed in paragraphs 104 to 112. Many of these institutions manage liquidity on a global or international basis. These models imply that funding activities, in the most important currencies, are entirely convertible. As noted by Northcott and Zelmer (2009), these same institutions do not automatically carry out a currency by currency precise gap management. McGuire and von Peter (2009) reported that the recent financial crisis was also accompanied by an important foreign currency funding crisis. As suggested by Duttweiler (2009), each liquidity monitoring tool should be first applied to each currency in which a bank has (important) obligations and following that be aggregated into its domestic currency. In the Consultative document, in paragraphs 110 to 112 on significant currencies, we suggest to extend the full regulatory standards and monitoring tools to each individual foreign currency designated as being a "very significant currency". Following paragraph 111, a "very significant currency" is defined as a currency in which claims and/or funding liabilities exceed or equal $5 \%$ of the bank's balance sheet total expressed in its domestic currency. Therefore, paragraph 134 on currencies should be amended in order to more vigorously address the issue of concentration of funding in each "very significant currency".

The third general comment, relates to the application issues for standards and monitoring tools discussed in paragraphs 130 to 135 inclusively. We agree with the Committee's proposal on the scope of application described in paragraph 133. As we argued in the second of our general comments, the proposed regulatory standards and 
monitoring tools should also be extended in paragraph 134 to each and every "very significant currencies". As for the frequency of calculation and reporting (regulatory), we believe that regular reporting of regulatory standards and monitoring tools metrics to investors should be strongly encouraged by bank supervisors. This reporting could be presented regularly in a bank's quarterly financial report to shareholders, or at least in its annual report. Lopez (2003) discussed the importance of disclosure as a supervisory tool, and he argued its merits as Pillar 3 of Basel II. More recently the BCBS $(2009,2008 \mathrm{a}, 2008 \mathrm{~b}, 2008 \mathrm{c})$ reiterated the importance of the public disclosure principle. Moreover, empirical results on various public disclosure studies carried out by the BCBS over the years (2003b, 2004, 2006), and by academic researchers such as Préfontaine et al. (2008a, 2008b, 2009a, 2009b) document the informational content and usefulness of regular and more complete disclosure of risk management information by banks and other financial institutions. In order to promote increased transparency, to improve risk management governance, and to foster greater financial market self-discipline we strongly suggest to increase the level and extent of financial risk management disclosure by internationally active banks. In paragraph 135, we suggest that information on the metrics, both on the standards and the monitoring tools, should be transparent and be publicly disclosed on a frequent and regular basis; like in a bank's quarterly financial report. We also suggest that qualitative information providing necessary explanations should support the numerical (quantitative) information given.

The fourth general comment aims at providing suggestions to extend the scope and use of "real" sector as well as financial market monitoring rules and metrics. Our comments on improving the coverage of market-related monitoring tools cover several paragraphs 123 to 129, and those on application issues for standards and monitoring tools also cover several other paragraphs 130 to 135 . As a result, the fourth general comment on monitoring rules and metrics will be presented in the form of several more precise specific comments.

\section{SPECIFIC COMMENTS}

The comments that follow are more specific; that is, they pertain to specific paragraphs of the Consultative document.

- $\quad$ On page 4 in paragraph 15 , it is said that more work on monitoring will be conducted in the area of intraday liquidity risk. We suggest to also carry out more work in the two following areas: intragroup and crossborder liquidity risks.

- $\quad$ On page 9 in paragraph 32, it is written that a bank should periodically monetise a proportion of the assets in its liquid asset buffer... Is this procedure really necessary? It could also send a wrong signal to other market participants. One possible alternative could be to periodically obtain reference prices from the market rather than carrying out transactions.

- $\quad$ On page 31 in paragraphs 131 and 132, there is some confusion in the explanations provided on frequency of calculation and reporting. In paragraph 131, it is said that metrics should be used on an ongoing basis... Banks are expected to meet the requirements of the standards continuously. However, in paragraph 132, confusion arises when it is said that: The metrics should be calculated and reported at least monthly...

- $\quad$ On page 31 in paragraph 134 on currencies, and if we refer back to our second general comment we add the following: If the bank's position in any given currency is judged to be very significant, it could be preferable to require that the two standards, LCR and NSFR, be calculated and respected for domestic currency positions and all other currencies judged to be very significant. The possibility of implementing this comment could be examined while carrying out calibrating work, or during the consultative period and quantitative impact study.

- The List of Abbreviations which appears in the text in front of Section 1. Introduction should also include "PD: Probability of default". In the List of Abbreviations ECAI is used to designate an External Credit Assessment Institution, that is why on page 10 in paragraphs 36 and 37 it is written... by a recognised external credit assessment institution (ECAI) which is clear. However, on page 15 in paragraph 60 , it is written... upon the downgrade... by a recognised credit rating organisation. On page 20 in paragraph 80 , it is written... bank analysts and rating agencies. Finally, on page 21 in paragraph 83 , it is written... by any nationally recognised credit rating organisation. 
- $\quad$ On page 2 in paragraph 9, it is written... The second objective (of the regulatory standards) is to promote resiliency. Given its importance, the term resiliency should be defined. Perhaps, this could be done close to paragraph 29 on page 8, where the terms market breadth and market depth are formally defined. Note that in paragraph 30 on page 8 , the first four lines and the last two practically explain what is generally meant by market resiliency.

- On page 5 in paragraph 20, we suggest to provide immediately the "exact definition" of the liquidity coverage ratio LCR which would be:

Stock of unencumbered high quality liquid assets $\geq 100 \%$

Net cumulative outflows over a 30-day time period

Instead of the definition provided which lacks precision:

$$
\frac{\text { Stock of high quality liquid assets }}{\text { Net cash outflows over a 30-day time period }} \geq 100 \%
$$

In fact, in order to obtain the "exact definition", a reader has to take into consideration the information provided elsewhere in paragraphs 21 and 26 and note 5 on page 6 . To obtain the "exact definition" of the denominator, a reader has to take into consideration the information provided much further in paragraph 38 on page 11.

- $\quad$ On page 6 in paragraph 22, the text discusses a market-wide shock which would result in: (a) a three-notch downgrade in the institution's public credit rating. Please clarify the three following points. (1) For most institutions, a three-notch downgrade may seem excessive. (2) Does the downgrade apply to an institution's long term credit rating like its subordinated debt, or its short-term money market funding instruments like CDs, or both? (3) Would it be more precise to say: in the institution's public credit rating allocated by a recognised ECAI?

- $\quad$ On page 9 in paragraph 34(b) and note 8, because some countries require banks to hold central bank reserves, while other countries do not, it would be important to clarify as soon as possible the inclusion (exclusion) of central bank reserves within the stock of liquid assets. The proposed agreement should contribute to obtain a more level "playing field".

- $\quad$ On page 9 in paragraph 41(a) Stable deposits... covered by an effective deposit scheme... In paragraph 44 on page 12, on foreign currency deposits: specify if these are covered or not covered by an effective deposit insurance scheme because this will also influence the appropriate run-off factor... In paragraph 53 on page 13, the text notes that the portion of these deposits, those from small business customers, that is fully covered by deposit insurance can receive the same treatment as "stable" retail deposits. Since the maximum amount of deposit insurance coverage can vary from one country or a group of countries to another, this will also impact upon the determination of both the LCR and NSFR regulatory standards. The BCBS should formulate a proposal to alleviate this problem in order to foster a more level "playing field".

- On page 25 in paragraph 95, it is written: if all flows occurred at the earliest possible date. This should be changed to: at the least favorable possible date. Moreover, the explanations provided on page 26 in paragraph 97 help to substantiate our comments: Asset flows... latest possible maturity. Liability cash flows... earliest possible date of outflow. Contractual cash flows.... earliest possible repayment date.

- $\quad$ On page 30 in paragraphs 123 to 129 inclusively, the importance of monitoring real sector information is never discussed. Both high frequency market data and perhaps less frequent real sector information are useful indicators in monitoring potential liquidity difficulties at banks. For example, paragraph 123 could be modified in this respect. 
- $\quad$ On page 30 in paragraph 127 on the financial sector... information to be monitored could be expanded to include reports by market analysts and recognized ECAIs. Also on page 30 in paragraph 128 on bankspecific information... Information to be monitored could also be expanded to include reports by market analysts and recognized ECAIs.

- $\quad$ On page 35 of Annex 2, ... Unencumbered corporate bonds or covered bonds which qualify for the 20\% RSF factor must have traded at a bid-ask-yield spread that has not exceeded $40 \mathrm{bsp}$ during the last 10 years or during a relevant period of significant liquidity stress, just like the recent 2007-2009 time period. Could the BCBS provide a reference justifying this condition? Similarly on page 35 of Annex 2,... Unencumbered gold, corporate bonds, covered bonds, and equity securities which qualify for the 50\% RSF factor must have traded at a bid-ask spread that has not exceeded 50 bsp during the last 10 years or during a relevant period of significant liquidity stress, just like the recent 2007-2009 time period. Could the BCBS provide a reference justifying this condition?

\section{CONCLUSION}

The market turmoil that began in mid-2007 re-emphasized the importance of liquidity to the functioning of financial markets, the banking sector as well as the world economy in general. Building on the findings of its earlier published work on liquidity risk management and supervision (2008a, 2008b, 2008c), in December 2009, the BCBS of the BIS released a consultative document entitled: International Framework for Liquidity Risk Measurement, Standards and Monitoring. Interested parties were invited to provide written comments by April 16th 2010. Given our fundamental and applied research interests (2009a, 2009b, 2008a, 2008b) in advancing sound liquidity risk management and supervision, members of the Desjardins Chair responded to the BIS request. In this conclusion, we share with the BCBS a summary of our analysis and comments. Our analysis leads us to fully support the adoption of the BCBS proposals on two new liquidity risk management standards which take the form of a 30-day minimum liquidity coverage ratio (LCR) combined with a one-year minimum net stable funding ratio (NSFR), both to be accompanied by a mandatory set of market-related monitoring tools. Second, we share with the BCBS several general comments and suggestions that were formulated on the following topics: the need to enhance coordination, both domestically and internationally between macro and microprudential supervision, the need to formulate and implement more precise liquidity risk requirements on foreign currency funding, the importance and usefulness of enhancing liquidity risk public financial disclosure, suggestions were also made on extending the use of real sector and market-related monitoring rules and metrics. Third, we shared with the BCBS more specific comments and suggestions were formulated on the following topics: areas of further work intra-group and cross border foreign currency liquidity risk management, selling financial assets to gauge market liquidity, clarifying the proposed LCR and NSFR definitions, major credit rating downgrades, and defining required stable funding categories. The results of our analysis also support the need for a more level business and supervisory playing field for all internationally active banks. In the case of this proposed framework for liquidity risk measurement, standards and monitoring, this would mean carefully considering the impact of country differences in the two following areas: required central bank reserves, and domestic deposit insurance coverage. As a result of the possible adoption of the proposed liquidity adequacy requirements (LAR), we should observe corresponding market pricing adjustments within LCR and NSFR components. Consequently, banking sector ROAs and ROEs could become relatively lower and more stable. For a while at least, some countries' banking sector which now benefit from a relatively strong financial position could be further advantaged. Notice however that no comments were formulated in this paper on the simultaneous BCBS-BIS proposals to strengthen banks' global capital.

\section{ACKNOWLEDGEMENTS}

Financial support from the Desjardins chair in sustainable development and the Research group in applied finance at Université de Sherbrooke is gratefully acknowledged. 


\section{AUTHOR INFORMATION}

Dr. Préfontaine is Professor of Finance at Faculté d'Administration Université de Sherbrooke, and Desjardins Chair in managing sustainable development. His professional, teaching and research interests have focused on financial institutions management, risk management and corporate social responsibility.

Dr. Desrochers is Professor of Finance and director of the undergraduate program at Faculté d'Administration Université de Sherbrooke, and research director of the Desjardins Chair in managing sustainable development. His professional, teaching and research interests have focused on portfolio theory, risk management and socially responsible investment.

Mrs. Godbout is a fourth year DBA student at Faculté d'Administration Université de Sherbrooke, and research assistant of the Desjardins Chair in managing sustainable development. Her professional, teaching and research interests have focused on financial institutions management, integrated risk management and corporate social responsibility.

\section{REFERENCES}

1. Basel Committee on Banking Supervision, (2009), "Consultative Document: International framework for liquidity risk measurement, standards and monitoring", Bank for International Settlements, December.

2. Basel Committee on Banking Supervision, (2008c), "Principles for Sound Liquidity Risk Management and Supervision”, Bank for International Settlements, Draft for Consultation, June $17^{\text {th }}$, Final Report, September.

3. Basel Committee on Banking Supervision, (2008b), "BCBS Announces Steps to Strengthen the Resilience of the Banking System", Bank for International Settlements, Press release, Basel, April $16^{\text {th }}$.

4. Basel Committee on Banking Supervision, (2008a), "Liquidity Risk: Management and Supervisory Challenges", Bank for International Settlements, Basel, February $21^{\text {st }}$.

5. Basel Committee on Banking Supervision, The Joint Forum, (2006), "The management of Liquidity Risk in Financial Groups", Bank for International Settlements, Basel, May.

6. Basel Committee on Banking Supervision, The Joint Forum, (2004), "Financial Disclosure in the Banking, Insurance and Securities Sectors: Issues and Analysis", Bank for International Settlements, Basel, May.

7. Basel Committee on Banking Supervision, (2003b), "Public Disclosures by Banks: Results of the 2001 Disclosure Survey", Basel Committee Publications, No. 97, May.

8. Boussanni, Abderrahim, Desrochers, Jean, Préfontaine, Jacques, (2008a), "Liquidity Risk Financial Disclosure: The Case of Large European Financial Groups", International Business \& Economics Research Journal, July, Vol. 7, No. 7, pp. 47-56.

9. Carney, Mark, (2008), "Speech by the Governor of the Bank of Canada to the Canada-United Kingdom Chamber of Commerce, London, England, November, pp. 1-7.

10. Committee of European Banking Supervisors, (2008), “Consultation Paper CP 19 on Liquidity Risk Management".

11. Desrochers, Jean, Préfontaine, Jacques, (2008b). "Comments to the BCBS: Principles for Sound Liquidity Risk Management and Supervision”, Bank for International Settlements, July, pp. 1-7.

12. Duttweiler, R. (2009), Managing Liquidity in Banks - A Top Down Approach, West Sussex, UK: John Wiley \& Sons Ltd.

13. Financial Stability Board, (2009), "High-Quality Liquid Assets Should Be Liquid in Markets during a Time of Stress and, Ideally Be Central Bank Eligible", September, Report to the G20.

14. G20, (2009a), "Declaration on Strengthening the Financial System", Ministerial Meeting of the Leaders of the G20, London, April.

15. G20, (2009b), "Declaration on Further Steps to Strengthen the Financial System", Meeting of Finance Ministers and Central Bank Governors, London, September.

16. G20, (2009c), "Enhancing Sound Regulation and Strengthening Transparency", Working Group 1, Final Report, March $25^{\text {th }}$.

17. Institute of International Finance, (2007), "Principles of Liquidity Risk Management", IFF, March. 
18. Lopez, José A., (2003), "Disclosure as a Supervisory Tool: Pillar 3 of Basel II”, FRBSF Economic Letter 2003-22, August $1^{\text {st }}$.

19. McGuire, Patrick, von Peter, Goetz, (2009), “The US Dollar Shortage in Global Banking”, BIS Quarterly Review, March, pp. 47-63.

20. Northcott, Carol Ann, Zelmer, Mark, (2009), "Liquidity Standards in a Macroprudential Context", Bank of Canada, Financial System Review, December, pp. 35-40.

21. Préfontaine, Jacques, Desrochers, Jean, Godbout, Lise, (2009a), "The Analysis of Comments Received by the BIS on: Principles for Sound Liquidity Risk Management and Supervision”. Ninth Annual IBER \& TLC Conference Proceedings, Las Vegas, Nevada, USA, October, pp. 1-8. Accepted for publication in July 2010 in the International Business \& Economics Research Journal.

22. Préfontaine, Jacques, Desrochers, Jean, Godbout, Lise, (2009b), "The Informational Content of Voluntary Embedded Value (EV) Financial Disclosures by Canadian Life Insurance Companies", International Business \& Economics Research Journal, December, Vol. 8, No. 12, pp. 1-13.

23. Senior Supervisors Group, (2008), "Leading-Practice Disclosures for Selected Exposures”, Financial Stability Forum, Bank for International Settlements, Basel, April $11^{\text {th }}$.

24. Senior Supervisors Group, (2008), "Observations on Risk Management Practices During the Recent Market Turbulence", Financial Stability Forum, Bank for International Settlements, Basel, March $6^{\text {th }}$. 
NOTES 